\title{
PENGARUH TOTAL QUALITY MANAGEMENT TERHADAP KINERJA KARYAWAN PT BCD BOGOR
}

\section{THE EFFECT OF TOTAL QUALITY MANAGEMENT TO EMPLOYEE PERFORMANCE AT PT BCD BOGOR}

\author{
I Zulkarnain ${ }^{1 a}$, D Gemina, E Yuningsih ${ }^{1}$ \\ ${ }^{1}$ Program Studi Management, Fakultas Ekonomi, \\ Universitas Djuanda Bogor, Jl. Tol Ciawi No.1 Kotak Pos 35 Bogor 16720 Indonesia \\ aKorespondensi: Iskandar Zulkamain E-mail: Iskandarzul1011@gmail.com \\ (Diterima: 17-12-2018; Ditelaah: 18-12-2018; Disetujui: 20-01-2019)
}

\begin{abstract}
This research aims to analysis employee performance which is influenced by total quality management (TQM) simultaneously and partially at PT BCD. Customer focus, continuous improvement, HR empowerment are the variables contained in TQM. Descriptive analysis method by using Likert scale of descriptive analysis. Verification analysis uses coefficient determination, correlation, and regression. Questionnaire was obtained from 100 employees in production, quality control, utility, and warehouse sections. The questionnaire was tested through validity, reliability, and classical assumptions. The results of the classical assumption test are valid, reliable thus can be used for regression. The test result of the coefficient of determination $\left(\mathrm{R}^{2}\right)$ is 68.40 percent thus other factors affecting is 31.60 percent. The relationship between TQM and employee performance is very strong (coefficient 0.827). Employee performance is influenced by the overall TQM. Partially customer focus and continuous improvement affect employee performance whereas empowerment toward the HR has no influence to the variable.
\end{abstract}

Keywords: Customer Focus, Continuous Improvement, Empowerment of Human Resources.

\section{ABSTRAK}

Penelitian bertujuan untuk menganalisis kinerja karyawan dipengaruhi oleh total quality management (TQM) simultan dan parsial di PT BCD. Fokus pelanggan, perbaikan berkesinambungan, dan pemberdayaan SDM variabel dalam TQM. Metode analisis deskriptif dengan Skala likert untuk analisis desktiptif, sedangkan untuk analisis verifikatif menggunakan koefisien determinasi, korelasi berganda, dan pengujian regresi. Data kuesioner didapatkan dari 100 orang karyawan bagian produksi, quality control, utility, dan gudang. Kuesioner teruji dengan uji validitas, uji reliabilitas, dan juga asumsi klasik. Hasil dari pengujian tersebut valid, reliabel dipakai untuk data regresi. Hasil pengujian koefisien determinasi $\left(\mathrm{R}^{2}\right)$ 68,40 persen, sedangkan faktor lain mempengaruhi 31,60 persen. Hubungan antara TQM dan kinerja sangat kuat karena hasil koefisien sebesar 0,827. Kinerja karyawan dipengaruhi oleh TQM secara keseluruhan (simultan). Secara parsial fokus pelanggan juga perbaikan berkesinambungan mempengaruhi kinerja karyawan, sedangkan variabel tidak berpengaruh adalah pemberdayaan SDM.

Kata kunci: Fokus Pada Pelanggan, Perbaikan Berkesinambungan, Pemberdayaan Sumber Daya Manusia.

Zulkamain, I., Gemina, D., \& Yuningsing, E. (2019). Pengaruh total quality management terhadap kinerja karyawan PT BCD Bogor. Jurnal Sosial Humaniora, 10(1), 40-48. 


\section{PENDAHULUAN}

Persaingan ketat dan terus berkembang lingkungan industri adalah seperti konsekuensi naiknya permintaan akan kualitas barang ataupun jasa yang diisyaratkan konsumen. Setiap organisasi mesti meningkatkan kinerja semua faktor dalam bisnisnya secara berkelanjutan agar membuahkan produk bermutu tinggi atau setidaknya sama dengan pesaing, bahkan lebih tinggi.

Menurut (Tjiptono, 2000), kualitas adalah dinamika yang berkaitan dengan produk, manusia, jasa, lingkungan, dan proses yang sesuai harapan pelanggan atau bahkan melebihi. Ada aspek-aspek utama operasionalisasi bisnis yaitu pemilik, manajer, karyawan, dan konsumen. Ada strategi-strategi meningkatkan kualitas, diantaranya dengan memperbaiki kinerja karyawan disemua lini perusahaan dengan sistematis dan berkesinambungan.

Pendekatan sistematis yang menggunakan beberapa dimensi untuk menaikkan mutu diantaranya definisi dari total quality management (TQM). Perencanaan telah diterapkan secara luas oleh banyak perusahaan. Tujuannya adalah meningkatkan performa seperti kualitas, produktivitas, dan profitabilitas. Dari berbagai artikel manajemen operasi bisa tahu sudah banyak perusahaan besar semua dunia yang telah mengaplikasikan TQM beberapa tahun terakhir. Disamping itu, para pakar kualitas telah banyak melakukan penelitian berkonsentrasi konsep TQM dengan meninjaunya dari berbagai substansi atau area yang berbeda. Mulai awal tahun 1980-an, TQM mendapatkan perhatian besar dari banyak manajer karena sudah terbukti dapat meningkatkan performa atau kinerja perusahaan. TQM merupakan pandangan mengoperasikan usaha dengan memperkuat kompetisi seluruh lini dalam lembaga berdasar fokus pelanggan, keterlibatan karyawan, perbaikan kualitas produk, manusia, lingkungan organisasi, jasa, operasional berkelanjutan (Krajewski, 2006)

PT BCD bergerak di bidang bisnis Toll In Manufacturing Beverage Filling Bussiness with Bottle Volume 200 500 ml dan Original Equipment Manufactur (OEM) Beverage Filling. Secara sederhana dapat dikatakan PT BCD membuat minuman kemasan botol 200-500ml dengan sistem pengisian steril (aseptic filling) dan automasi. PT BCD menghasilkan minuman milik perusahaan lain yang telah menjadi pelanggannya. PT BCD memiliki dua area produksi. Line pertama mulai memproduksi minuman pada Desember 2012, sedangkan line kedua dimulai Maret 2015. Kapasitas produksi per bulan PT BCD mencapai 30.000.000 botol pada dua area produksi. PT BCD sudah menerapkan TQM sejak tahun 2012.

Pada lima (5) tahun sejak produksi pertama, tingkat produk PT BCD tidak sama persyaratan pelanggan (reject) masih sangat tinggi. Produk reject ini bisa diakibatkan kekeliuran proses produksi, bahan baku tidak sesuai, ataupun hasil produk yang diluar persyaratan pelanggan. Produk reject yang dihitung merupakan produk akhir yang sudah dinyatakan tidak masuk pengkhususan ditetapkan perusahaan dan pelanggan. Data produk reject dari tahun 2015 Juni 2017 berikut.

Gambar 1.Rekapitulasi Produk Reject Per Semester PT BCD Periode Tahun 2015-2017

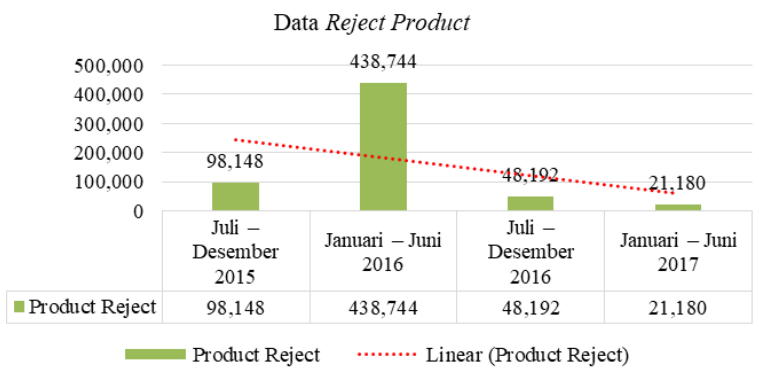

Indikator kinerja karyawan lainnya adalah kuantitas. Kuantitas bisa dianalisis pencapaian target produksi. Setiap bulan manajemen PT BCD telah menentukan target produksi yang harus dicapai. Pencapaian target produksi di PT BCD semester awal 2017.

Gambar 2. Rekapitulasi Yield Lost Produksi PT BCD Periode Januari - Mei 2017

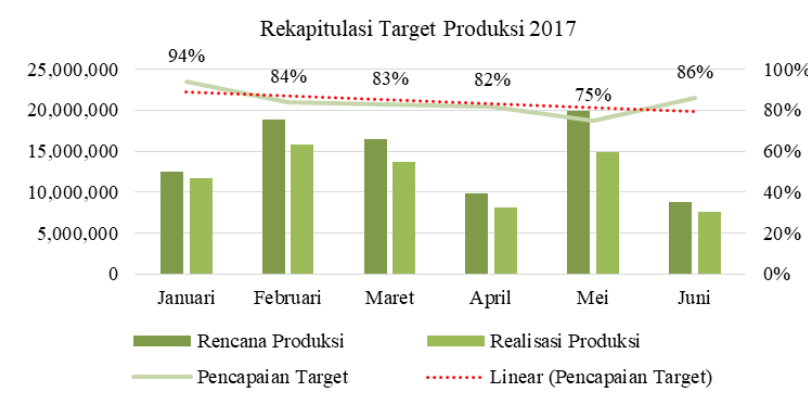

Kinerja PT BCD belum optimal di tahun terakhir. Maka, peneliti mengambil judul "Pengaruh TQM terhadap Kinerja Karyawan PT BCD". Tujuannya adalah menganalisis tanggapan karyawan PT BCD pada pelaksanaan TQM dan kinerjanya di PT BCD. Menganalisis variabel- 
variabel TQM yaitu fokus kepada pelanggan, perbaikan kesinambungan, dan pemberdayaan SDM dapat mempengaruhi tingkat kinerja karyawan secara simultan dan parsial.

\section{MATERI DAN METODE}

\section{Total Quality Management (TQM)}

Menurut (Blocher, dkk 2000) bahwa TQM merupakan usaha yang dilakukan perusahaan secara kontinu tiap-tiap orang pada lembaga agar paham, memenuhi, melebihi keinginan pelanggan. Adapun indikator TQM terdiri dari: a) Berfokus kepada pelanggan; b) Berusaha keras melakukan perbaikan yang berkelanjutan dengan keras; c) Melibatkan semua kekuatan kerja (karyawan).

\section{Fokus Pelanggan}

Whitely dalam Goetsch (2002) ada 7 (tujuh) karakteristik yang harus dimiliki perusahaan agar berhasil mewujudkan konsentrasi kepuasan yaitu visi perusahaan, komitmen manajemen, suasana kerja, penjajaran perusahaan dengan para pelanggan, kemauan dalam mengidentifikasi keluhan pelanggan, mengatasi keluhan pelanggan, memanfaatkan info didapat pelanggan, mendekati pelanggan, kesanggupan dan kemampuan manajemen dalam memberdayakan sumberdaya manusia, dan yang terakhir adalah melengkapi produk juga proses.

\section{Perbaikan Berkesinambungan}

Perbaikan berkesinambungan adalah proses koreksi dikerjakan berkesinambungan dan sistematis. Lima kegiatan dasar pembaharuan berkesinambungan (Tjiptono, 2000), yaitu komunikasi, merapikan masalah jelas/nyata, memandang ke hulu, mendokumentasikan kemajuan masalah setelah perbaikan, dan memantau perubahan yang dilaksanakan menghilangkan masalah.

\section{Pemberdayaan Karyawan}

Pemberdayaan SDM ialah sebuah konsep pemberdayaan yang menggunakan energi kreatif, pengalaman, kapabilitas psikologis seluruh karyawan dengan cara memperlakukan karyawan hormat, memberi karyawan informasi yang mereka butuhkan dan selalu melibatkan karyawan mengambil keputusan yang sesuai bidang keahlian karyawan (Gaspersz, 2002). Dari pengertian tersebut, dapat diketahui indikator keberhasilan pemberdayaan karyawan tergantung pada tiga aspek penting yaitu sikap manajemen kepada karyawan, persembahan informasi ke karyawan, dan pelibatan karyawan dalam menentukan keputusan yang sama dengan keahlian karyawan.

\section{Kinerja Karyawan}

Kesesuaian antara akuntabilitas dilimpahkan ke karyawan dengan keluaran kerja bisa dilihat perspektif kuantitas juga kualitas (Mangkunegara, 2004). Indikator kinerja dipakai mengetahui bagaimana kinerja karyawan telah mengalami kemajuan acara menggapai target maupun tujuan organisasi. Indikator kinerja dapat diketahui pada aspek kualitas kerja, kuantitas hasil pekerjaan, pelaksanaan tugas, akuntabilitas karyawan.

\section{Pengembangan Hipotesis}

Ada beberapa riset yang mengamati pengaruh TQM pada kinerja karyawan, ialah (Munizu, 2010). Hasil riset membuktikan variabel TQM; perencanaan strategis, kepemimpinan, fokus pelanggan, manajemen SDM, informasi dan analisis, dan manajemen proses mempunyai dampak positif signifikan pada aspek kinerja karyawan. Tujuan dari bisnis pada dasarnya menghasilkan lalu mempertahankan pelanggan. Pada pendekatan TQM, kualitas sangat ditentukan oleh pelanggan. Oleh sebabnya mengenal proses juga pelanggan, organisasi juga sadar untuk menghargai kualitas. Usaha manajemen TQM dikendalikan fokus utama, yakni berbentuk kepuasan (Tjiptono, 2000). Oleh karena, itu dalam penerapan unsur TQM yaitu fokus terhadap pelanggan secara langsung perusahaan akan meningkatkan kinerja karyawannya. Ada beberapa pendapat yang membahas pengaruh fokus pelanggan pada kinerja. Salah satunya pendapat (Prajogo, 2008), bahwa fokus kepuasan pelanggan ialah faktor mikro dari lembaga mempengaruhi perubahan dan pengembangan kinerja suatu organisasi, juga satu diantara elemen secara signifikasi mempengarui kinerja karyawan.

Pembaharuan berkelanjutan ialah komponen mendasar TQM. Konsep pembaharuan berkelanjutan ditetapkan pada proses produk juga orangnya. Kaizen ialah rekaan jepang artinya pembaharuan berkesinambungan. Pendekatan bisa sukses jika diikuti usaha tepat karyawan. 
Aspek manusia ialah elemen terpenting pembaharuan mutu juga produktivitas (Tjiptono, 2000). Oleh sebab itu, perbaikan berkesinambungan berpengaruh pada kinerja. Ada beberapa riset pengaruh pembaharuan berkesinambungan pada kinerja. Salah satunya dalam riset dilaksanakan (Al-Shobaki, 2010). Dari riset terdapat hubungan signifikansi positif pembaharuan berkesinambungan pada kinerja.

Pemberdayaan bisa diartikan pelibatan karyawan, tanpa adanya pemberdayaan, penyertaan karyawan cuma alat menajemen tidak berguna, sebabnya pelibatan juga diikuti pemberdayaan. Pelibatan karyawan ialah proses ikut serta karyawan disegala tahapan organisasi membuat keputusan juga pemecahan masalah (Nasution, 2005). Sehingga kinerja karyawan perusahaan bisa dipengaruhi pemberdayaan karyawan. Ada beberapa riset pengaruh permberdayaan SDM pada kinerja. Satu diantaranya riset (Mansour, 2012) terdapat keterkaitan signifikasi juga positif keterlibatan juga pemberdayaan pada kinerja. Semakin besar organisasi melakukan pelibatan juga pemberdayaan baik untuk karyawan makin baik pula kinerja karyawannya. Dari tiga pendapat dan hasil riset diatas, maka hipotesisnya adalah: TQM pengaruhi positif signifikasi pada kinerja; Fokus pelanggan pengaruhi positif signifikasi pada kinerja; Perbaikan berkesinambungan pengaruhi positif signifikasi pada kinerja; Pemberdayaan SDM pengaruhi positif signifikasi pada kinerja.

Gambar 3 tersebut memperlihatkan kerangka pemikiran.

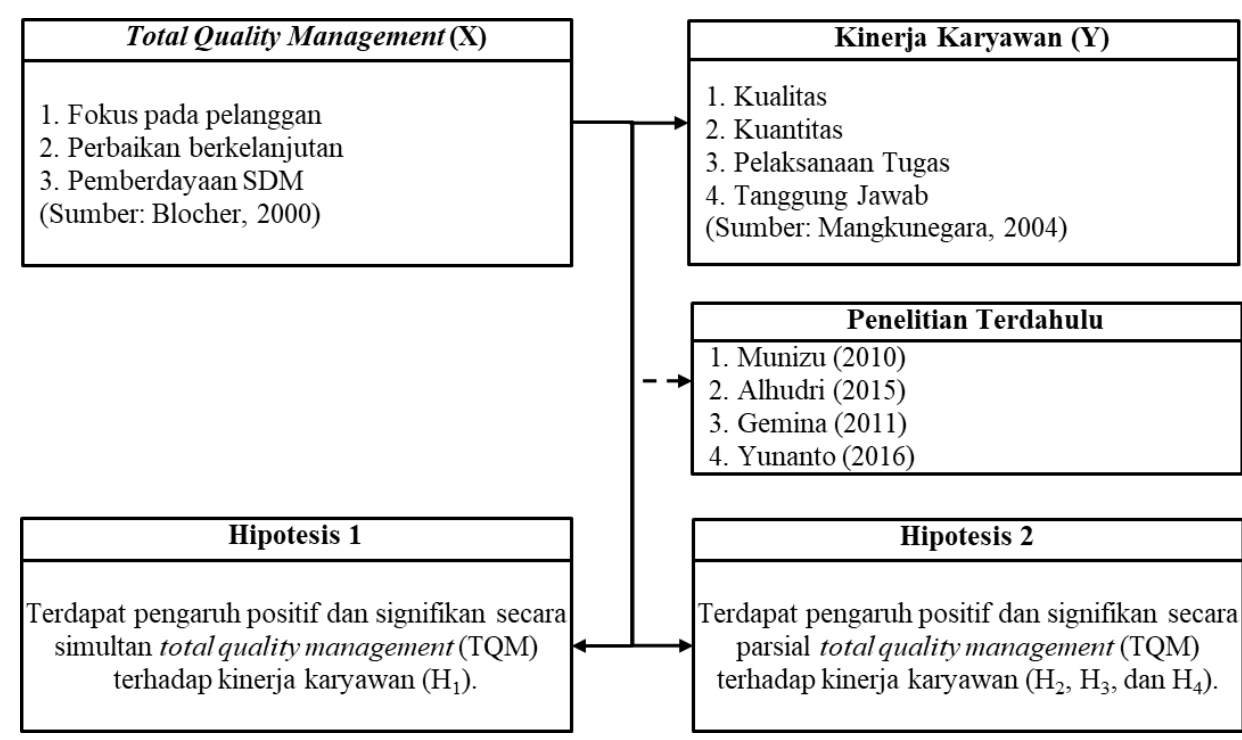

\section{Metode Penelitian}

Objek penelitian karyawan PT BCD yang berlokasi di Jalan Raya Ciawi-Sukabumi KM 3 Bitung Sari, Kabupaten Bogor. PT. BCD bergerak di bidang bisnis Toll In Manufacturing Beverage Filling Bussiness with Bottle Volume 200 500 ml dan OEM Beverage Filling. Secara sederhana dapat dikatakan PT BCD menghasilkan minuman kemasan botol 200-500ml dengan sistem pengisian steril (aseptic filling) dan automasi. Unit analisis penelitian yaitu karyawan PT BCD dengan populasi karyawan bagian produksi, quality control, gudang, dan utility sebanyak 142 orang. Untuk menentukan responden dijadikan sampel karyawan PT BCD, maka teknik penentuan sampel yang dianggap representatif memakai rumus slovin didapatkan hasil sample sebanyak 100 orang. Untuk mengetahui ukuran sampel karyawan disetiap bagian dilakukan proporsional random sampling. Penentuan jumlah sampel dan porsi pada setiap departemen didasarkan pada perhitungan berikut.

Tabel 1. Sampel Karyawan PT BCD Dengan Stratified Random Sampling

\begin{tabular}{llcc}
\hline No & $\begin{array}{c}\text { Nama } \\
\text { Bagian }\end{array}$ & $\begin{array}{c}\text { Jumlah } \\
\text { Karyawan }\end{array}$ & $\begin{array}{c}\text { Ukuran Sampel } \\
\text { Karyawan } \\
\text { (Pembulatan) }\end{array}$ \\
\hline 1 & Produksi & 85 & $85 / 142 \times 100=58$ \\
2 & QC & 21 & $21 / 142 \times 100=15$ \\
3 & Utility & 12 & $12 / 142 \times 100=12 *)$ \\
4 & Gudang & 24 & $24 / 142 \times 100=17$ \\
\hline & Jumlah & $\mathbf{1 4 2}$ & $\mathbf{1 0 0}$ \\
\hline
\end{tabular}

Penelitian memakai metode deskriptif juga verifikatif diperoleh pemilahan data PT BCD. Penelitian ini menggunakan data primer didapat penyebaran kuesioner. Data lain dipakai data sekunder dari olah data primer itu sendiri (Siagian, 1999) Pengujian data menggunakan uji 
validitas, reliabilitas, uji asumsi klasik yaitu uji normalitas, uji multikolonieritas, dan uji heterokedastisitas. Setelah semua instrument diuji, selanjutnya dilakukan regresi linear berganda, korelasi berganda, koefisien determinasi, pengujian hipotesis secara simultan (Uji F) dan terakhir adalah pengujian secara parsial (Uji t).
Operasionalisasi variabel penelitian adalah kumpulan definisi berdasarkan pada karakteristik yang diobservasi dari apapun yang didefinisikan atau mengganti konsep kalimat yang dapat diuraikan sesuai perilaku, dapat diamati, dapat diuji, serta dapat ditentukan kebenarannya. Semua operasionalisasi variable : TQM, kinerja karyawan berikut ini.

Tabel 2. Operasionalisasi Variabel

\begin{tabular}{|c|c|c|c|}
\hline Variabel & Sub Variabel & Konsep Sub Variabel & Indikator \\
\hline \multirow[t]{3}{*}{$\begin{array}{l}\text { Total Quality } \\
\text { Management }(\boldsymbol{X}) \\
\text { TQM adalah } \\
\text { merupakan usaha } \\
\text { yang dilakukan } \\
\text { perusahaan secara } \\
\text { kontinu tiap-tiap } \\
\text { orang pada } \\
\text { lembaga melebihi } \\
\text { keinginan } \\
\text { pelanggan. } \\
\text { (Brocher,2000) }\end{array}$} & $\begin{array}{l}\text { a. Fokus Pada } \\
\text { Pelanggan }\left(\mathrm{X}_{1}\right)\end{array}$ & $\begin{array}{l}\text { Merupakan usaha untuk } \\
\text { memproduksi berdasar kemauan } \\
\text { pelanggan agar pelanggan puas } \\
\text { (Tjiptono, 2000). }\end{array}$ & $\begin{array}{l}\text { 1.Visi perusahaan, komitmen manajemen, } \\
\text { dan suasana kerja } \\
\text { 2.Penjajaran pelanggan } \\
\text { 3.Mendekati pelanggan } \\
\text { 4.Memanfaatan info pelanggan } \\
\text { 5. Kemauan identifikasi permasalahan } \\
\text { pelanggan juga mengatasi maslaah } \\
\text { 6.Kemampuan, kesanggupan, } \\
\text { pemberdayaan }\end{array}$ \\
\hline & $\begin{array}{l}\text { b.Perbaikan } \\
\text { Berkesinambungan } \\
\left(\mathrm{X}_{2}\right)\end{array}$ & $\begin{array}{l}\text { Proses pembaharuan kontinu } \\
\text { dilaksanakan sistematis. } \\
\text { (Tjiptono, 2000). }\end{array}$ & $\begin{array}{l}\text { 1. Komunikasi } \\
\text { 2.Perbaiki masalah jelas/nyata. } \\
\text { 3.Pemecahan akar masalah } \\
\text { 4.Mendokumentasikan kemajuan } \\
\text { perbaikan masalah dan } \\
\text { perkembangannya } \\
\text { 5.Memantau deformasi }\end{array}$ \\
\hline & $\begin{array}{l}\text { c. Pemberdayaan } \\
\operatorname{SDM}\left(\mathrm{X}_{3}\right)\end{array}$ & $\begin{array}{l}\text { Konsep memakai energi kreatif } \\
\text { pengalaman, kekuatan intelektual } \\
\text { seluruh karyawan dengan cara } \\
\text { memperlakukan karyawan dengan } \\
\text { hormat, memberi karyawan } \\
\text { informasi dan melibatkan karyawan } \\
\text { mengambil keputusan sesuai } \\
\text { bidang keahlian karyawan } \\
\text { (Gaspersz, 2002). }\end{array}$ & $\begin{array}{l}\text { 1. Sikap manajemen kepada karyawan } \\
\text { 2. Pemberian info ke karyawan } \\
\text { 3. Pelibatan mengambil keputusan }\end{array}$ \\
\hline \multirow{4}{*}{$\begin{array}{l}\text { Kinerja } \\
\text { Karyawan (Y) } \\
\text { adalah kesesuaian } \\
\text { antara tanggung } \\
\text { jawab dibebankan } \\
\text { bandingkan } \\
\text { keluaran kerja } \\
\text { kuantitas juga } \\
\text { kualitas. } \\
\text { (Mangkunegara, } \\
\text { 2004) }\end{array}$} & a. Kualitas & $\begin{array}{l}\text { Merupakan seberapa baik } \\
\text { mengerjakan pekerjaan. }\end{array}$ & $\begin{array}{l}\text { 1. Ketepatan } \\
\text { 2.Ketelitian } \\
\text { 3.Keterampilan } \\
\text { 4.Kebersihan hasil kerja } \\
\text { 5.Kesempurnaan tugas }\end{array}$ \\
\hline & b.Kuantitas & $\begin{array}{l}\text { Merupakan berapa lama karyawan } \\
\text { bekerja satu hari. }\end{array}$ & $\begin{array}{l}\text { 1. Kecepatan } \\
\text { 2.Jumlah keluaran } \\
\text { 3.Jumlah aktivitas }\end{array}$ \\
\hline & $\begin{array}{l}\text { c. Pelaksanaan } \\
\text { tugas }\end{array}$ & $\begin{array}{l}\text { Merupakan seberapa baik } \\
\text { karyawan bisa melaksanakan } \\
\text { pekerjaannya akurat. } \\
\text { Komponennya terdiri kehandalan } \\
\text { menyelesaikan tugas, pengetahuan } \\
\text { tentang pekerjaan, kesadaran } \\
\text { kewajibannya. }\end{array}$ & $\begin{array}{l}\text { 1.Kehandalan } \\
\text { 2.Pengetahuan } \\
\text { 3. Kesadaran dan kewajiban melaksanakan } \\
\text { pekerjaan }\end{array}$ \\
\hline & d.Tanggung Jawab & $\begin{array}{l}\text { Merupakan kesadaran karyawan } \\
\text { akan kewajibannya untuk } \\
\text { melakukan kerjaan diberikan. }\end{array}$ & $\begin{array}{l}\text { 1. Kesanggupan menyelesaikan tugas } \\
\text { 2.Memikil risiko keputusan. }\end{array}$ \\
\hline
\end{tabular}




\section{PEMBAHASAN}

\section{Karakteristik Rekapitulasi Karyawan}

Berdasarkan data diperoleh bahwa mayoritas karyawan ialah laki-laki berusia 25-36 tahun, berlatar belakang pendidikan akhir SMU/Sederajat, sudah kerja PT BCD selama lebih dari 5 tahun, bekerja di bagian produksi, dengan jabatan sebagai operator atau analis.

Gambar 5. Rekapitulasi Hasil Kuesioner

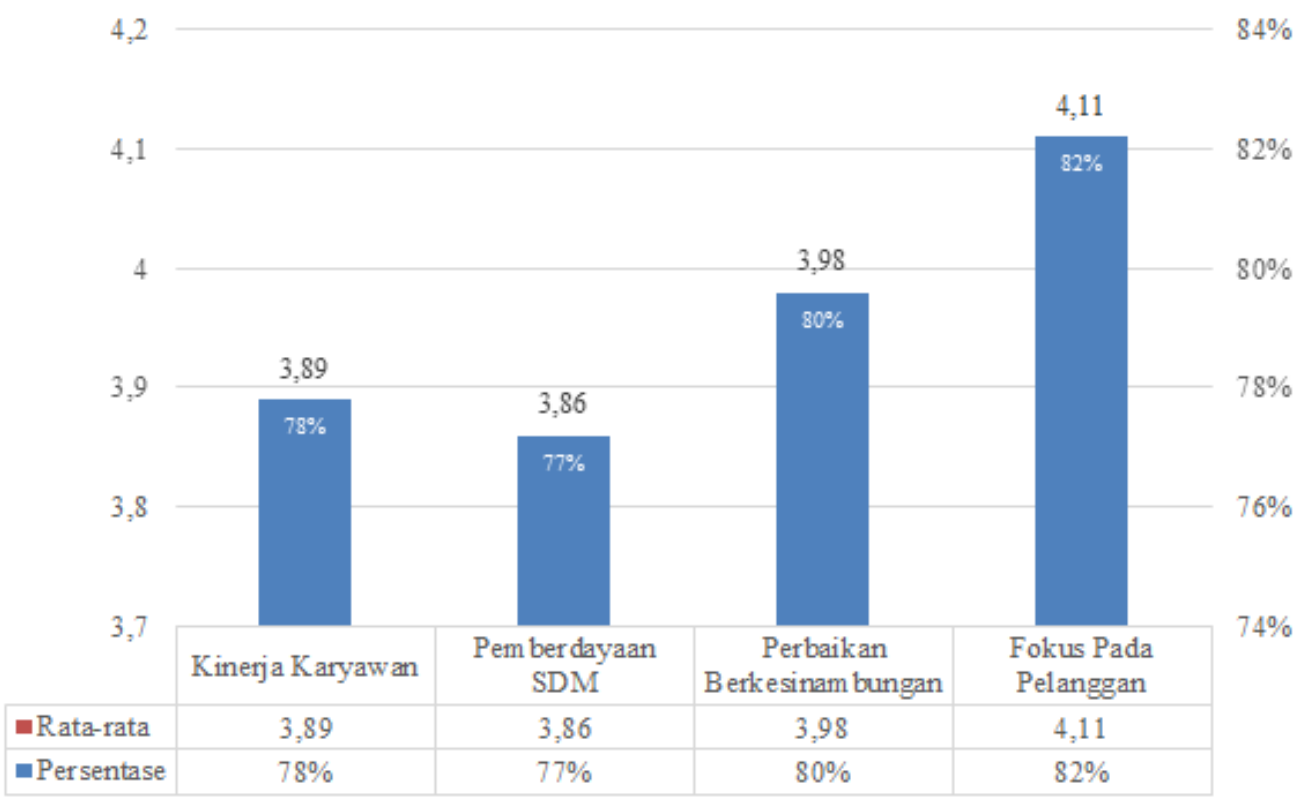

Pada Gambar 5 tanggapan karyawan tentang fokus pelanggan di PT BCD sebesar 82 persen menjawab fokus pelanggan di PT BCD sudah dalam kategori baik. Tanggapan karyawan terhadap perbaikan berkesinambungan memiliki nilai 80 persen menjawab perbaikan berkesinambungan di PT BCD sudah dalam kategori baik. Tanggapan karyawan terhadap nilai pemberdayaan SDM sebesar 77 persen berpendapat pemberdayaan SDM di PT BCD sudah dalam kategori baik. Tanggapan karyawan terhadap nilai kinerja karyawan sebesar 78 persen berpendapat kinerja karyawan sudah dalam kategori tinggi.

\section{Uji Validitas dan Reliabilitas Instrumen Penelitian}

Uji validitas dilakukan dengan tujuan mengukur pernyataan atau pertanyaan dalam kuesioner. Validitas sebuah data dinyatakan terpenuhi jika pernyataan atau pertanyaan itu bisa ungkap sesuatu. Berdasarkan pengujian instrument kepada tiga puluh (30) karyawan menunjukkan bahwa uji validitas terkait variabel bebas fokus pelanggan, pembaharuan berkelanjutan, pemberdayaan SDM, dan variabel terikat yakni kinerja karyawan bisa dikatakan valid, dapat dilanjutkan ke pengujian reliabilitas.

Uji reliabilitas ialah alat pengukur kuesioner semua indikator variabel, kuesioner dinyatakan reliable jawaban dari seseorang terhadap sebuah pertanyaan atau pertanyaan dapat konsisten waktu ke waktu, (Sugiyono, 2015). Berdasarkan pengujian instrument penelitian kepada tiga puluh (30) karyawan menunjukkan bahwa dari seluruh fokus pelanggan, pembaharuan berkelanjutan, pemberdayaan SDM, kinerja diperoleh hasil jika seluruh item reliabel karena memiliki Cronbach Alpha > 0,6.

\section{Uji Asumsi Klasik}

Hasil uji yaitu a) Uji normalitas bahwa data dinyatakan terdistribusi normal; b) Uji multikolonieritas tidak multikoloni antara variabel bebasnya; c) Uji heterokedastisitas tidak heterokedastisitas dari semua model regresi 
sehingga semua model regresi dapat dilanjutkan ke uji regresi linear berganda.

\section{Hasil Pengolahan Data}

Analisis data memakai SPSS type 22.0 diperoleh hasil persamaan berikut:

Tabel 3. Rangkuman Hasil Perhitungan TQM Terhadap Kinerja Karyawan PT BCD.

\begin{tabular}{|c|c|c|c|c|c|}
\hline \multirow{2}{*}{ Model } & \multicolumn{2}{|c|}{ Unstandardized Coefficients } & \multirow{2}{*}{$\begin{array}{c}\text { Standardized } \\
\text { Coefficients } \\
\text { Beta }\end{array}$} & \multirow{2}{*}{$\mathbf{t}$} & \multirow{2}{*}{ Sig. } \\
\hline & $\mathbf{B}$ & Std. Error & & & \\
\hline (Constant) & 3.533 & 2.756 & & 1.282 & .203 \\
\hline Fokus Pada Pelanggan & .739 & .183 & .396 & 4.046 & .000 \\
\hline Perbaikan Berkesinambungan & .500 & .129 & .367 & 3.871 & .000 \\
\hline Pemberdayaan SDM & .167 & .116 & .136 & 1.443 & .152 \\
\hline $\mathrm{t}$-tabel & $=1.990$ & & & & \\
\hline F-hitung & $=69,269$ & & & & \\
\hline Sig & $=.000$ & & & & \\
\hline F Tabel & $=3.090$ & & & & \\
\hline & $=.827$ & & & & \\
\hline $\mathrm{R}^{2}$ & $=.684$ & & & & \\
\hline Adjusted $\mathrm{R}^{2}$ & $=.674$ & & & & \\
\hline Alpha $(\alpha)$ & $=5 \%$ & & & & \\
\hline
\end{tabular}

Berdasarkan ringkasan hasil perhitungan menggunakan regresi berganda dipakai bisa menjelaskan 68,4 persen dari variabel dependen sedangkan sisanya 31,6 persen pengaruhi oleh lain diantaranya yang dipaparkan (Tjiptono, 2000) yaitu obsesi pada kualitas, pendekatan ilmiah, kebebasan terkendali, komitmen jangka panjang, pendidikan pelatihan, kerjasama tim, dan kesatuan tujuan. Sedangkan nilai R sebesar 0,827 yang artinya hubungan antara variabel TQM dan variabel kinerja karyawan sangat kuat. Kepercayaan 95 persen variabel TQM secara simultan pengaruh kinerja. Secara parsial fokus pelanggan juga pebaikan berkesinambungan mempengaruhi positif signifikan, sedangkan pemberdayaan SDM tidak pengaruhi positif siginifikan.

\section{Pengaruh Fokus Pelanggan, Perbaikan Berkesinambungan, dan Pemberdayaan Sumber Daya Manusia Terhadap Kinerja Karyawan pada PT BCD}

Hasil pengujian diperoleh Fhitung 69,269, dengan signifikansi 0,000, dan menggunakan batas signifikansi $0,05(\alpha=5 \%)$, adapun derajat kebebasan $\mathrm{df}=3-1=2 \mathrm{dan} \mathrm{df}=100-3-1=96$ sebesar 3,090. Hasil pengujian didapat (Fhitung > Ftabel) dan (sig $<\alpha$ ), Ho ditolak dan Ha diterima. Artinya kepercayaan 95 persen variabel independen TQM secara simultan pengaruhi kinerja.

(Tjiptono, 2000)mengungkapkan bahwa implementasi TQM dibanyak perusahaan Jepang dan Amerika menunjukkan perbaikan kinerja, produktivitas, profitabilitas, dan juga daya saing perusahaan. Penelitian sama dengan (Alhudri, 2015) yang hasilnya TQM secara bersama-sama (simultan) pengaruhi positif signifikan pada kinerja. Begitu juga penelitian (Gemina, 2015), pada UKM. Penelitian menerangkan dalam menghadapi situasi globalisasi (persaingan bebas), maka UKM juga Koperasi perlu menerapkan TQM pada sistem usahanya agar meningkatkan potensi dari UKM juga Koperasi. Dapat disimpulkan semua variabel TQM harus berjalan optimal karena secara simultan pengaruhi kinerja.

\section{Pengaruh Fokus Pelanggan $\left(\mathrm{X}_{1}\right)$ Terhadap Kinerja Karyawan}

Hasil pengujian diperoleh nilai thitung fokus pelanggan pada kinerja menampilkan nilai 4,046 dengan probabilitas 0,000. Adapun derajat kebebasan ttabel $(0,05 ; 100-3$ - 1$)(0,05 ; 96)$ sebesar 1,990 dan menggunakan batas signifikansi $0,05(\alpha=5 \%)$, diketahui $(4,046>$ $1,990)$ dan $(0,00<0,05)$, Ho ditolak dan $\mathrm{Ha}$ diterima. Dapat disimpulkan kepercayaan 95 persen, fokus pelanggan pengaruhi kinerja positif signifikan.

Hal ini sama dengan teori (Gaspersz, 2002), pelanggan ialah seluruh yang menuntut karyawan organisasi mencapai standar tertentu karena bisa memberi dampak kinerja atau kinerja perusahaan. Visi perusahaan dijalankan dengan baik memberikan pengaruh sangat penting unsur fokus pada pelanggan. Sesuai dengan pendapat (Tjiptono, 2000) yang mengungkapkan bahwa visi terpenting mengembangan kapabilitas strategik yang menertapkan posisi perusahaan. 
Visi punya posisi utama karena menentukan masa depan perusahaan dan memberi sense of direction bagi semua individu yaitu karyawan.

Selain visi perusahaan yang dijalankan dari dalam organisasi, perusahaan juga perlu dekat dengan pelanggan memberikan servis yang baik. Perolehan penilaian disampaikan oleh pelanggan perlu diteruskan kepada seluruh karyawan agar dapat menumbuhkan kepedulian akan kepuasan para pelanggan. Hasil audit dari pelanggan, keluhan pelanggan, dan informasi penting dari pelanggan selalu di respon dengan cepat sehingga dapat jadi elemen pendorong kinerja PT BCD. Hasil penelitian sama dengan (Alhudri, 2015), secara parsial fokus pelanggan pengaruhi positif signifikasi pada kinerja PT PLN Ranting Bangkinang. Begitu pun penelitian (Munizu, 2010) yang menyatakan fokus pelanggan secara parsial pengaruh kinerja karyawan positif signifikan pada PT Telkom Cabang Kota Makassar.

\section{Pengaruh Perbaikan Berkesinambungan $\left(X_{2}\right)$ Terhadap Kinerja Karyawan}

Hasil pengujian diperoleh nilai thitung untuk variabel pembaharuan berkelanjutan pada kinerja menampilkan 3.871 dengan probabilitas 0,000 . Adapun derajat kebebasan ttabel 1,990 dan menggunakan batas signifikansi $0,05(\alpha=$ $5 \%)$, diketahui $(3.871>1,990)$ dan $(0,000<$ 0,05 ) artinya Ho ditolak juga Ha diterima. Dengan kepercayaan 95 persen disimpulkan perbaikan berkesinambungan mempengaruhi kinerja positif juga signifikan.

Menurut (Tjiptono, 2000), peningkatan kinerja juga berasal dari perbaikan sistem/proses, tidak hanya merupakan peningkatan kemampuan sumber daya. Hasil riset sejalan (Karahan, 2012) pada industri manufaktur di Turki mengatakan perbaikan berkesinambungan pengaruh kinerja. Kegiatan pelaporan masalah di PT BCD dilakukan pada meeting harian untuk mendengarkan laporan karyawan tentang kendala-kendala yang dihadapi. Nilai tanggapan tentang poin pelaporan ini tinggi karena karyawan merasa mempunyai wadah untuk menyampaikan masalah pada pekerjaannya, walaupun terkadang terkendala dengan bahasa saat berkomunikasi dengan presiden direktur. Dengan pelaporan permasalahan karyawan, manajemen dapat mengetahui kendala yang ditemui dilapangan dengan jelas sehingga dapat dilakukan perbaikan dengan cepat. Hal itu mendorong kinerja karyawan PT BCD.

\section{Pengaruh Pemberdayaan SDM ( $\left.\mathrm{X}_{3}\right)$ Terhadap Kinerja Karyawan}

Hasil pengujian diperoleh nilai thitung untuk variabel pemberdayaan SDM pada kinerja menampilkan 1,443 dengan probabilitas 0,152. Adapun derajat kebebasan ttabel 1,990 dan menggunakan batas signifikansi $0,05(\alpha=5 \%)$, diketahui $(1,443<1,990)$ dan $(0,152>0,05)$ Ho diterima dan Ha ditolak. Dengan kepercayaan 95 persen disimpulkan pemberdayaan SDM tidak pengaruhi kinerja positif signifikan. Berdasarkan beberapa wawancara yang dilakukan penerapan pemberdayaan SDM perlu penghargaan yang jelas dari manajemen agar karyawan termotivasi untuk selalu memberikan ide ataupun sarannya kepada perusahaan. Sistem sumbangan saran yang sudah diimplementasikan di PT BCD sudah cukup baik, namun kurang memotivasi karyawan untuk berperan aktif. Motivasi diberikan berupa reward bagi ide karyawan yang baik, seperti perusahaan-perusahaan kelas dunia. Hal ini mesti diperhatikan perusahaan selain mengimplementasikan saran dari karyawan, perlunya reward untuk mendorong motivasi karyawan dalam menyumbangkan sarannya demi pertumbuhan organisasi dan perusahaan.

(Gaspersz, 2002) mencontohkan sistem yang diimplementasikan oleh perusahaan Aisin Warner yaitu pihak manajemen mendorong partisipasi karyawan dengan berusaha supaya karyawan bebas mengungkapkan saran yang tidak memerluakan dana tinggi untuk menerapkannya. Berbagai saran akan melalui penilaian dasar juga sekunder sebelum diterima atau ditolak. Setiap saran yang baik akan diberikan hadiah dalam waktu satu minggu setelah saran itu diajukan.

(Tjiptono, 2000) mengungkapkan bahwa manajer tradisional sering beranggapan pemberdayaan SDM akan menjadikan kekuasaan para manajer tersebut menjadi turun. Manajer tersebut diliputi rasa takut apabila karyawan selalu diikutkan. Mereka beranggapan bahwa memindahkan kendali perusahaan kepada para karyawan. Hasil riset sama dengan (Seputra, 2014), pemberdayaan SDM tidak memberikan pengaruh signifikasi pada kinerja salah satu cabang bank di Surabaya. 


\section{KESIMPULAN}

Kesimpulan penelitian ini adalah Hasil rekapitulasi tanggapan karyawan pada penerapan TQM yaitu fokus pelanggan, pembaharuan berkelanjutan, dan pemberdayaan SDM menyatakan bahwa nilai terbesar dari tiga (3) variabel tersebut adalah fokus pelanggan, sedangkan nilai terkecilnya adalah pemberdayaan SDM. Sedangkan rekapitulasi tanggapan kinerja menyatakan jika nilai terbesar adalah ketepatan dan nilai terkecil adalah jumlah produk yang dihasilkan. Dari perolehan hitungan simultan membuktikan bahwa hipotesis fokus pelanggan, pembaharuan berkelanjutan, dan pemberdayaan SDM pengaruhi kinerja positif signifikan. Perolehan hitungan parsial yaitu fokus pelanggan, pembaharuan berkelanjutan pengaruhi kinerja positif signifikan. Sedangkan pemberdayaan SDM tidak pengaruhi kinerja positif signifikan pada PT BCD. Faktor pendukung dimensi TQM pada kinerja ialah fokus pada pelanggan juga perbaikan berkesinambungan. Sedangkan faktor penghambat dalam dimensi TQM pada kinerja ialah pemberdayaan SDM yang kurang maksimal.

Sedangkan implikasinya diantarnya: Peningkatan kinerja karyawan, perlu komitmen dari manajemen tingkat atas, menengah, dan bawah untuk melaksanakan TQM keseluruhan dan aktif.; Mengoptimalkan pemberdayaan karyawan dengan memberikan insentif bagi saran karyawan untuk memotivasi karyawan agar terus melibatkan diri pada perbaikan sistem kerja di area masing-masing. Cara tersebut sudah sering dilaksanakan perusahaan-perusahaan kelas dunia; Melakukan perawatan mesin dengan mencegah cacat lebih baik perbaikan setelah kerusakan. Mengganti part mesin yang asli lebih direkomendasikan agar kerusakan mesin dapat tekan sehingga produksi tidak terhambat dan hasil produksi dapt mencapai target; Memanfaatkan informasi karyawan tentang perbaikan-perbaikan yang disampaikan karyawan agar karyawan merasa diberdayakan.

\section{DAFTAR PUSTAKA}

Alhudri Said, Meyzi Heryanto. 2015. Pengaruh Penerapan Total Quality Management (TQM) Terhadap Kinerja Karyawan Pada PT. PLN (Persero) Ranting Bangkinang. Jurnal FISIP, Vol. 2, No. 2, pp 1-14

Arikunto, Suharsimi. 2004. Prosedur Penelitian: Suatu pendekatan Praktek. Bandung. Rineka Cipta.
Blocher, J. Edward, Kung H. Chen, Thomas W. Lin. 2000. Manajemen Biaya. Terjemahan, Jakarta. Salemba Empat.

Gaspersz, Vincent. 2002. Total Quality Management. Cetakan Kedua. Jakarta. PT Gramedia Pustaka Utama.

Gemina Dwi, Endang Silaningsih, Titiek Tjahya Andari. 2015. Implementasi Total Quality Management Berkaitan dengan Manajerial Perusahaan dan Keunggulan Bersaing (Implementation of Total Quality Management Related to Company Managerial and Competitive Advantage), Jurnal Aplikasi Manajemen, Vol. 13 No. 1, pp 149-157

Handoko, T. Hani. 2011. Dasar-dasar Manajemen Produksi dan Operasi. Edisi I. Yogyakarta. BPFE

Karahan Mehmet. 2012. The Determination of the Effect Level on Employee Performance of TQM Practices with Artificial Neural Networks: A Case Study on Manufacturing Industry Enterprises in Turkey, International Journal of Business and Social Science, Vol. 3 No. 7, pp. 133-142

Krajewski, J. Lee dan P. R. Larry. 2006. Operations Management Strategy and Analysis. Fifth Edition. Addison-Wesley Publising Company Inc.

Mangkunegara, A. Anwar Prabu. 2004. Manajemen Sumber Daya Manusia Perusahaan. Bandung. PT Remaja Rosdakarya.

Munizu, Musran. 2010. Praktik Total Quality Management (TQM) Dan Pengaruhnya Terhadap Kinerja Karyawan. (Studi Pada PT. Telkom. Tbk. Cabang Makassar). Jurnal Manajemen dan Kewirausahaan, Vol. 12, No. 2, pp 185-194

Prajogo, Daniel I., and Soon W. Hong. 2008. The Effect of TQM Performance in $R \& D$ environments: A Prespective form South Korean Firms, Technovation 28, pp 885-863

Riduwan. 2006. Rumus Dan Data Dalam Aplikasi Statistika. Bandung. CV Alfabeta.

Seputra I Gede Krishna Pradana. 2014. Pengaruh TQM Terhadap Kinerja Karyawan Bagian Operasional PT. Bank X Cabang Surabaya, Artikel Ilmiah, STIE Perbanas, Surabaya (eprints perbanas.ac.id diakses pada tanggal 09 Desember 2018, Pukul 11.58 WIB)

Siagian, D dan Sugiarto. 2006. Metode Statistika untuk Bisnis dan Ekonomi. Jakarta. Gramedia Pustaka Utama.

Sudrajat M. 1999. Statistika Non Parametric. Fakultas Perbankan Jatinangor. Bandung. Universitas Padjadjaran. 
Sugiyono. 2015, Metode Penelitian, Kuantitatif, Kualitatif, dan R\&D. Cetakan Ke-22. Bandung. CV. Alfabeta.

Tjiptono, Fandy dan Anastasia Diana. 2000. Total Quality Mangement. Edisi: Revisi. Yogyakarta. Andi. 